\title{
Ao fim desta estrada...
}

\author{
Lucas Florêncio Costa
}

- Não vou criar meus filhos no cabo da enxada! Nóis tem é que ir pro Sul, Neco. Nesse roçado não dá mais não. Socorrinho tá que não se aguenta aqui e eu não quero perder mais um fil...

Manoel aproximou seu enorme e descarnado corpo de Maria, a abraçou e antes que sua mulher terminasse a frase, rompeu seu silêncio - Ô Maria, tu pensa bem mulher! São Paulo não é esse paraíso que cê tá pensando não...

Manoel lembrava cada trecho, palavra e silêncio daquela conversa. Até porque havia se passado somente uma semana e meia desde que ela acontecera. Ele vinha remoendo aqueles instantes na memória desde que entrara no ônibus, rumando pra São Paulo. Lembrava-se do pano azul de Maria, presente de uma comadre, enfaixando o cabelo mal escovado dela. Recordava-se do cheiro da vasta cozinha da casa que moravam. Redesenhava em sua cabeça o cenário, puxando na memória o fogão de lenha e a sensação de sua quentura tímida. Num canto do ambiente uma mesinha à meia altura sem nada por cima, do outro lado um banco talhado no tronco de um mulungu, tudo pairando sobre o chão de terra batida. Neco lembrava até da luz que entrava pela única janela do recinto. Era uma luz tão forte que espremia os olhos de qualquer um que a visse. Era tão clara que tilintava num clarão. Era a luz do raiar de um dia qualquer do ano de 1966.

$\mathrm{O}$ casal era pai de seis crianças. Com sua mulher, Maria Muniz (que era uns quinze anos mais nova que ele), Neco havia conseguido a duras dores criar os seis filhos. Não que isso seja algo bonito de se escrever, pois o casal, na verdade, tivera 17 filhos. É que lá pr'aquelas bandas, o árido Pernambuco, cada pedaço de chão ecoa um desafio indizível. E naquele cenário, de inconfundível imensidão, Maria e Neco criaram três meninos e três meninas.

Há uns dois anos a mulher colocara na cabeça que deveria ir para o Sul. Desde que uma comadre lhe enviara uma carta do Rio de Janeiro reportando "todas as coisas mais bonitas que há de se ter nesse mundo de Deus" e que 
sua irmã, Maria José, fora morar com o esposo em S. Paulo, Maria Muniz não tirou da imaginação o plano de descer no mapa, rumo a uma vida sem miséria. Já Manoel, ou melhor, Neco (como a mulher gostava de chamá-lo) ainda esperançava uma vida melhor no sertão. Ele vira os avós e os pais morrerem naquelas terras e até então não se via muito longe de lá. E essa dualidade de expectativas era motivo de muitas e longas conversas do casal. Maria firme e decidida; Neco cheio de titubeios!

Enfim chegou o dia em que Neco se decidira e mesmo Maria há tempos desejosa da viagem, era a palavra do marido que havia de definir aquilo. Arranjos desta sociedade! Antes mesmo de anunciar sua chegada, parou diante da porta da cozinha - à qual mal comportava sua volumosa imagem, pois embora fosse magérrimo, sua estrutura óssea era qualquer coisa de monumental. Seu enorme corpo era abraçado pelo Sol do meio dia, que batia em suas costas. Neco então passou os olhos por todo o ambiente, percebendo o teto, o chão, as paredes... o calor pacifico que saía do fogão Ihe chamou especial atenção. Ali, ele estivera por anos! Sua mulher, que até então estava de costas para ele, virada ao fogão à escolher feijão, por fim olhou-o. Maria, que era dessas pessoas que, ainda que mal lesse, interpretava o mundo e as pessoas com uma destreza inegável, viu nos olhos do marido uma inquietude inédita.

- Ôxi, o que você tem? Vai entrar não? Maria indagou.

Olhando para Maria, como poucas vezes havia olhado, com uma voz baixa, tão distante de sua costumeira fala, Manoel desabafou - Decidi Maria! Decidi...

- Decidiu o quê homem? Que conversa é essa? Neco procurou sua banqueta de madeira, olhou para os lados e ao encontrá-la puxou-a com uma mão e se sentou - Nóis vamo pra São Paulo, ainda esse mês!

- Como é que é? Maria então largou a cuia de feijão que vinha segurando desde que Neco entrara.

- Vai eu e Zé. Depois vai você e os outro menino tudo. Dentro de uns... três meses, a gente tá pra lá, tudo junto.

Titubeando uma reação, Maria se pôs a chorar. Encostou-se ao fogão e puxando o pano da cabeça, começou a enxugar as lágrimas que caíam. A notícia soara como um coice no peito dela. Ao mesmo tempo em que sorria internamente, pois sua intenção finalmente se faria aceita, sabia que o desfile do tempo traria mais amargura por conta desta mesma decisão e por isso chorava e chorava. O marido, agora decidido, levantou-se e seu enorme corpo pôs-se a ocupar quase toda a entrada da cozinha, que era também a entrada da casa. Virou-se de costas para Maria e saiu para o terreiro. Estava gélido internamente, pois imerso na vontade de um melhor destino, mas assombrado pelo medo da mudança, do incerto.

Dezesseis dias depois, estava ele e o filho José, que era o mais velho dos seis filhos, dentro de um precário ônibus com destino a São Paulo. E é bom dizer 
que adjetivar aquele transporte como um "precário ônibus" soa quase como um elogio: era mesmo um remendo metálico.

José era um rapazote que tinha lá seus 15 anos e já apresentava uma estatura formidável, tendo já alcançado o pai em altura! No aspecto físico puxara o pai, como se costuma dizer. As pernas do jovem, demasiadamente grandes e magras, mal cabiam entre o espaço de sua poltrona com a da frente. Assim, fizera boa parte da viagem com parte das pernas para fora da janela. Manoel vinha na poltrona do lado, junto ao filho. Seu imenso corpo também não se acomodava no espaço destinado à ele, mas sendo quem era, contentara-se em esticar uma das pernas no corredor esburacado do ônibus. Neco trazia consigo um saco de pano, de tamanho médio. Ali levava o documento dele e do filho, a carta de sua cunhada onde constava o endereço dela, uma banda de bolo de massa puba e uma lata de biscoito com carne e farinha. Os alimentos que eram pra durar toda a viagem, que se estenderia por uns cinco dias, se acabaram no arremate do segundo dia de viagem. A fome era medonha!

Manoel e o filho haviam de aguentar uns dois dias e meio à base de farinha, que era a única coisa que sobrara. José mal se aguentava no banco e se remexia constantemente, como se lutasse com o desconforto. Por vezes levava um cutucão do pai, gesto que só chateava mais o inquieto e famélico jovem! Por fim dormiram; já era a noite do terceiro dia e a viagem já superara seu meado. Estavam a percorrer o sul mineiro, pela escura e estonteante estrada.

Foi na madrugada do quarto dia que se sucedeu o que marcaria aquela viagem!

Neco acabara de acordar; há alguns minutos o filho se mexera tanto na poltrona que o espaçoso homem despertara. Com a preocupação no caminho, não voltou a dormir. Pôs-se a rezar e pensar como poderia vir a ser a sua vida e a vida dos seus. Encostava a cabeça no banco e pensava no que ainda não existia... desencostava a cabeça e punha-se a imaginar seu amanhã, fiando incertezas tão numerosas quanto os vazios do caminho que desfilava pela janela. Por umas duas vezes Neco, sem saber, recitara internamente o poeta recifense da vida severina... aquilo o acalmava. Na sua prospecção, a sombra de um mau pensamento se desenhou. O homem olhou o escuro caminho que mal se desenhava à frente. A sombra enigmática em sua mente aumentara. Com o braço direito chamou o filho - Zé... acorda! O rapazote se revirou, fugindo do chamado paterno - Zé, Zé... acorda!

MEU DEEEUUUS!!! Um grito de homem, vindo da frente do ônibus. Era o motorista. O ônibus de repente sacolejou para a direita. Um alvoroço! As pessoas começaram a gritar, as malas dançaram no ar e caíram no chão. $E$ num piscar de cílios, o encanecido ônibus foi desandando para a esquerda. Um estrondo! Era o pneu esquerdo! O ônibus solavancou repentinamente e num liso e angustiante movimento foi tombando para o lado esquerdo, aproximando-se a cada segundo do chão. O ônibus declinava em sua capotagem e levava consigo 
toda a gente. E num desses momentos em que nosso corpo é tomado por uma energia inexplicável que nos faz ser ou fazer aquilo que nem sequer supomos possível, Manoel se agarrou fortemente ao banco com seu poderoso braço esquerdo e com o outro lado de seu corpo prendeu o do filho José, que estava a acordar, tamanho era o susto. José também se agarrou ao banco.

Gritos, muitos gritos! Um coral esquizofrênico e aterrorizante de gritos! 0 ônibus beijou violentamente o chão! O estarrecedor rugido do metal estatelando no chão, a poeira da estrada tomando toda estrutura do precário transporte, que agora encostada ao chão tinha todos os vidros quebrados e toda parte esquerda de sua extensão meio que retorcida. O volumoso carro deslizou uns 15 metros na estrada; um novo solavanco, o ônibus girou em si duas vezes, arrebentando com a gente em seu interior. Apesar dos gritos nada se ouvia ou se via! O ônibus deslizava no barranco, que ia se esfacelando com o peso do carro, serenando a fatalidade da cena. O ônibus enfim parou onde a estrada, em seu lado direito, vinha a dar. Em 10 segundos a viagem se transformou na mais tirana das léguas.

A névoa de poeira deitou-se sobre todo o espaço, como se fosse um enfeite trágico do acontecido. Agora, um silêncio torturante rasgava o cenário, dominando-o do cume das colinas mineiras, que circundavam a estrada e os corpos retirantes estatelados pelo caminho. No capotar do ônibus Manoel bateu com as costelas no braço do banco, o que o presenteou com duas fraturas; Zé beijou com parte da face o banco da frente, que o empurrou para trás; na capotagem quase não saiu do lugar, pois era tão desproporcional ao espaço que ficou preso entre os bancos. Sua descomunalidade o salvou! O corredor do ônibus era lavado pelo rubro fluído dos corpos esfacelados pelo acidente.

Manoel levantou-se e mesmo atordoado pela dor, assombrou-se com a cena. O pânico e o medo dançavam à sua frente. Já acostumado com a dureza da vida, seu espanto durou apenas um pestanejar. Revistou todo o ônibus sem sair do lugar e com a força implícita que guia as grandes pessoas foi carregar os corpos da gente para fora do ônibus. $O$ saldo era de quatro mortes e dezenas de corpos escangalhados, como se fossem desarranjos humanos. Manoel conduziu para fora do ônibus uns 20 corpos. Carregava-os como uma criança carrega um brinquedo, pois sob sua imagem de magreza cadavérica se escondia uma força física vinda não sei de onde, assim como a fé que o acompanhava desde menino. Depois de um punhado de instantes se deu a lembrar do filho, que ele havia ajudado a descer do desalinhado transporte... onde Zé está? Ergueu seu corpo procurando ver o filho. Avistou-o sentado, à beira da estrada, segurando um objeto no meio das imensas pernas. Foi para lá, para próximo do filho e quanto mais se aproximava o objeto ia ficando mais nítido. O rapaz estava sentado, debruçado sobre uma lata de metal da qual pescava com as mãos pedaços de carne seca. 
- José! Uma desgraceira dessa e você comendo, meu filho?

O jovem José ergueu seu rosto para o pai, mas não o respondeu.

- De quem é isso? De quem é essa comida?

- Sei não pai.

A estrada estava ainda escura, embora faltasse pouco a principiar o amanhecer.

O jovem José, já tão habituado com a dureza de sua terra, mas ainda tão ingênuo em sua condição de criança crescida, queria somente acabar com aquilo que o vinha afligindo há dias...

E Manoel, homem traçado com as cores inconfundíveis do sertão, deixou seu filho ali; foi se sentar mais além. Deixou as vistas se perderem naquela vastidão assustadora e mal iluminada. E por alguns instantes se sentiu pequeno, como há muitíssimo tempo não se sentia; sentiu frio, sentiu fome. Foi abraçado por uma inexplicável vertigem... e por fim, sentiu medo de tudo. Ali sentado à beira daquela estrada buscou conforto em sua fé e perdoou, em silêncio, seu destino.

Foram longos instantes e por nenhum momento deixou Zé sair de seu olhar. Ele olhou para o filho, distante alguns poucos metros e que agora cambaleava de sono e chorou intensamente em seu peito, pois em sua sabedoria de homem simples, Neco sabia que ao fim daquela incerta estrada, seu menino teria de ser um homem. 